\title{
Responding to Cultural Challenges during the Covid-19 Pandemic as a Strategy to Build New Traditional Norms towards a Green Indonesia
}

\author{
Iriyanto Widisuseno, ${ }^{*}$ Sri Sudarsih \\ Faculty of Humanities, Diponegoro University, Semarang 50275, Indonesia
}

\begin{abstract}
During the adaptation of the new normal, there are fundamental and complex social changes, so that it is a cultural challenge for the people of Indonesia during the pandemic. Because they must instantly change collectivist living habits to a life pattern that is physically distant. The purpose of this research is to uncover and answer these cultural challenges as a strategy to build new traditional norms towards a green Indonesia. This study uses a cultural approach, with descriptive qualitative methods, and analysis based on the theory of evolution. The results of the study show that several cultural challenges, such as the problem of low community compliance in implementing health protocols, people's habits in socializing closely are a reflection of the collectivist cultural patterns that the Indonesian people have so far. Lack of understanding about the invisible dangers of the virus, as well as the emergence of various opinions through social media that do not support prevention efforts due to the low literacy culture. In conclusion, it is necessary to moderate collectivistic culture and community literacy as a strategy to build new traditional norms towards a green Indonesia.
\end{abstract}

\section{Introduction}

The crisis due to the Covid-19 pandemic that has hit the world community has no sign of ending. Even recently, WHO Director Tedros Adhanoaik Ghebreyesus stated that the current impact of the COVID-19 disease is not just a public health crisis but a crisis that has penetrated all aspects of humanity [1]. Such a crisis gives an understanding that the solution is medically sufficient and requires a comprehensive solution covering all aspects of the cultural behavior of the community.

This perspective rests on the assumption that disease outbreaks and sociocultural aspects are two things that cannot be separated. In practice, we cannot deny that disease is often caused by human culture (way of life), or disease is

*Corresponding author : widisusenoiriyanto@yahoo.co.id 
easy to become an epidemic due to certain behaviors or cultures in society. On the other hand, the disease also has a tremendous impact on aspects of human culture. World history has noted that various disease outbreak handlers, cholera, are known to arise from the culture or behavior of using poor sanitation facilities and not by health rules. The spread of cholera is due to an unclean lifestyle [2]. From experience above, what can we understand when cases of the spread of Covid -19 in Indonesia continue to increase over time. As an example of how high the rate of acceleration of the spread of Covid-19 was during the early period of the Covid-19 pandemic in Indonesia, from March-July 2020, additional data of 2,657 positive cases were reported on July 9, 2020, bringing the total number of Covid-19 cases in Indonesia in just five months as many as 70,736 people. In the map of transmission in the world made by Johns Hopkins University in the United States, Indonesia with that number of cases is in 26 countries with the most population infected with the coronavirus that causes the disease [3].

Meanwhile, cases of the spread of Covid-19 in Indonesia as of 19/07/2021 July 2021 experienced a jump up to 2,911,733 [4]. The description clarifies that efforts to resolve the problem of the Covid-19 outbreak in Indonesia will be increasingly difficult because it is faced with the cultural challenges of the community. For this reason, it is necessary to have every citizen's mental readiness to adapt to the new order of living habits during the Covid-19 pandemic. According to Novri Susan, the response system in dealing with the Covid-19 pandemic in Indonesia relies not only on how the state system works but also on reciprocity with the community [5]. This means that no matter how reasonable government regulations regarding the prevention of Covid-19 are, there is no benefit without the active participation of the community. Every individual in society must build each other's readiness to face the new average era during the Covid-19 pandemic, especially in adapting health protocols and social distancing. For example, by getting used to complying with health protocols that teach the values of discipline, they will shape their habits and social environment to live healthily and respect the environment.

Cultural theory teaches humans a lot about their ability to adapt. Compared to other creatures, humans have complete equipment to fulfill their natural needs to better adapt to the environment. The simplest example of a cultural approach to controlling Covid-19 is in Japan. Japan's experience in controlling Covid-19 without doing Lockdown but through an appeal, policy to avoid $3 \mathrm{C}$, namely people are not in closed spaces, crowded places, and close-contact. Japan has so far been considered quite successful in controlling the spread of the Corona Virus -19.[6]. According to Kartini, New Normal is a new term in Indonesian culture, how when people live together, they must separate themselves into new 
habits physically. In reality, the current impact of the New Normal has caused culture shock and even cultural tension for most Indonesian people. At the beginning of the New Normal, it is understandable if there is cultural tension because adaptation requires social and psychological processes for each individual. There is much knowledge about what Covid-19 is during the adaptation process, various aspects of the danger, and how to avoid it. This experience can increase literacy about the dangers of Covid-19, encourage and create a sense of self-awareness for each individual to build healthy behavior and culture. New Normal is a cultural transformation from traditional everyday living habits to a new order of living habits. Cultural tension and inflammation occur when there is a shift from collectivist community traditions that must switch to physical distancing patterns. All bonds of social cohesiveness are physically separated. The problem now is the extent to which the resilience and cultural elasticity of the Indonesian people are adapting the New Normal with all the Health Protocol and Social Distancing regulations. In this transformation process, various cultural challenges emerged for the Indonesian people. What are the cultural challenges during the COVID-19 pandemic? How to answer that problem as a strategy to build a new order of living habits to build a green Indonesia? Cultural challenges must be interpreted as things that inspire determination to improve problem-solving abilities or stimuli to work harder because there are positive values behind these challenges. Green Indonesia is defined as a country where all its people have habits of behavior and a culture of living clean, disciplined, healthy, and respecting the environment. So, how do Indonesian people who have collectivist, conformational, irrational, metaphysical habits of behavior and culture adapt to the new order of living habits that are all rational, practical, and pragmatic? The process of cultural transformation during the current pandemic, which is full of challenges, needs to be interpreted positively as Indonesia's strategy to change the order of old living habits that do not support a healthy living culture in order to get used to the new regular order of life to prevent the spread of the Corona Virus -19 .

\section{Method}

This study uses qualitative research and content analysis. Robert Bogdan (1992) said that qualitative research reveals the qualitative aspects of the socio-cultural phenomena of society [7]. This study focuses on analyzing the quality of sociocultural phenomena, namely revealing the meaning behind socio-cultural events among the Indonesian people when facing the new normal during the Covid-19 pandemic. The research data was obtained through documentary and literature studies. The primary data source is from the Covid-19 Response Document of Central Java Province (16/05/2021), while secondary data is obtained from 
related reference sources. The document found data on the high level of health protocol violations as a phenomenon of the cultural challenges of the people of Central Java in facing the Covid-19 pandemic. The magnitude of the level of violation of health protocols is dominated by social groups of private workers and the male sex. They are collecting data by analyzing the following steps: (a) identifying data, namely seeing the value contained in social phenomena related to the cultural challenges of society during the Covid-19 pandemic, (b) classifying and summarizing parts of social phenomena that have challenging values. Community culture during the Covid-19 pandemic, (c) interpreting the content of cultural challenges, and (d) discussing and concluding the analysis results. Philosophical abstraction and reflection can be practiced to capture the meaning of a social phenomenon, the text before being extracted into a deep narrative.

\section{Result and Discussion}

Among the people of Central Java, there are social phenomena that describe people's disobedience to implementing health protocols, people's habits in socializing closely, misunderstandings about the dangers of the virus, and various opinions among the community that does not support Covid-19 prevention efforts.

Result. This social phenomenon was revealed in the results of the operation against the Covid-19 response process in Central Java Province [8]. The data on violations based on the stratification of social groups, gender, and age groups can be seen in the table below.

Table 1. of Data on Health Protocol Violations in Central Java-Indonesia.

\begin{tabular}{|l|l|l|l|}
\hline No & Social Group & Gender & Age Group \\
\hline 1. & Private workers $82 \%$ & Male $79.58 \%$ & Age 20-39 years $50.45 \%$ \\
\hline 2. & Student/student $16.82 \%$ & Female 20.42\% & 40 years old 30.54\% \\
\hline 3. & PNS/Polri/TNI 0.57\% & & Age 19 and under $19,01 \%$ \\
\hline
\end{tabular}

Source: Tanggap Covid-19 Provinsi Jawa Tengah

The meaning behind the data can be explained that the highest level of health protocol violations in Central Java, namely in the private worker group, reached $82 \%$. The dominance of male sex is $79.58 \%$, female is only $20.42 \%$.

Discussion. The high percentage of violators in the private sector can be explained by Darwin's theory of evolution, that human adaptation is gradual, little by little. On the one hand, private-sector workers work under pressure to achieve productivity and profit, but on the other hand, they are faced with health protocol rules. Their challenge is faced with the natural selection process to 
survive, support themselves and their families. This also applies to male private workers. So Darwin's theory of evolution encourages a person to choose to adapt by surviving according to his environmental system at work. The new ordinary policy for them is something new that is felt to cause cultural tension because adaptation requires social and psychological processes in each individual. That is why they are taking their evolutionary path by violating health protocols. Then why PNS / TNI / Polri, students/students at least violate the health protocol / PPKM, because from the start they are (work, study, go to school), they are conditioned and accustomed to the normative rules of their environment to behave and have a healthy culture, discipline, respect for the environment. According to William Kilpatrick (1965), one of the causes of a person's inability to behave well, even though he cognitively knows it (moral knowing), is because he is not trained to do good or moral action.

For this reason, it is not enough for people to provide knowledge about goodness but must continue to guide them to the implementation stage in their daily lives [8]. Lickona (1992) emphasizes the importance of three components of good character, namely moral knowing or knowledge of morals, moral feelings or feelings about mental and moral actions or moral actions. This is necessary to understand, feel, and work simultaneously on the values of virtue (8). It is true what Novri Susan (2021) said, the response system in dealing with the Covid-19 pandemic in Indonesia does not only rely on how the state system works but there is reciprocity or reciprocity with the community [9]. This means that no matter how reasonable government regulations regarding the prevention of Covid-19 are, there is no benefit without the active participation of the community. Every individual in society must build each other's readiness to face the new average era during the Covid-19 pandemic, especially in adapting health protocols and social distancing [10].

\section{Conclusion}

Based on the discussion results above, it can be concluded that overcoming the Corona-19 Virus outbreak cannot be separated from a cultural approach, although it requires a health solution. During the Covid-19 pandemic, there was a process of cultural transformation resulting from the adaptation of the New Normal. The thing that needs to be considered is the extent to which the resilience and elasticity of the community's culture adapt to the new order of living habits during the Covid-19 pandemic. New Normal is a new civilization, requires socio-cultural transformation and brings various implications and consequences. Through Covid-19, this can become a historical momentum because many parties are taught something new towards a green Indonesia. For example, the homecoming tradition is not sacred but rather situational and 
functional through social distancing. Guarding against the crowd teaches to be more proportional to maintain a powerful gathering tradition. In terms of environmental maintenance through health protocols, the community becomes more preventive about the cleanliness of themselves and the surrounding environment. With all that, a green Indonesia will be achieved.

\section{References}

[1] Allian, 2021. Memahami Lebih Jelas Covid-19. Sumber: https://www.allianz.co.id/explore/detail/yuk-pahami-lebih-jelas-arti-pandemi-pada-covid19/101490. Diakses, 20 Juli 202, Jam 19.00

[2] Agung Nugroho: New Normal Momentum Transformasi Sosial, shttps://ugm.ac.id/id/berita/19479-new-normal-momentum-transformasi-sosial-budaya

[3] Zacharias Wuragil, 2020. Pseta Penularan Covid-19 Dunia, Jumlah Kasus Indonesia Dekati Cina. Sumber: https://tekno.tempo.co/read/1363303/peta-penularan-covid-19-duniajumlah-kasus-indonesia-dekati-cina/full\&view=ok. Diakses, 21 Juli 2021, jam 21.00

[4] Tatang Guritno, 2021. UPDATE: Tambah 34.257 Orang, Total Kasus Covid-19 Indonesia Sumber: $\quad$ ttps://nasional.kompas.com/read/2021/07/19/16383861/update-tambah-34257orang-total-kasus-covid-19-indonesia-2911733?page=all. Diakses 21 Juli 2021, jam 21.00

[5] Tim Komunikasi Publik Gugus Tugas Nasional, 2020. Tantangan Adaptas Kebiasaan Baru Dalam Budaya Masyarakat Indonesia. Sumber: https://covid19.go.id/p/berita/tantanganadaptasi-kebiasaan-baru-dalam-budaya-masyarakat-indonesia. Diakses, 16 Juli 202, Jam 08.00

[6] Luthfia Ayu Azanella, Kompas.com - 31/05/2020, 3C, Rahasia Jepang Kendalikan Covid19 Tanpa Berlakukan Lockdown? Sumber: https://www.kompas.com/tren/read/2020/05/31/140000465/3c-rahasia-jepangkendalikan-covid-19-tanpa-berlakukan-lockdown? Diakses, 21 Sept 2021, jam 23.00.

[7] Robert Bogdan dan Taylor, Pengantar Metode Penelitian Kualitatif,Terjemahan oleh Arief Rurchan, (Surabaya : Usaha Nasional, 1992:30].

[8] Sudarsono, 2021. Tanggap Covid-19 Provinsi Jawa Tengah (16/05/2021). Sumber: https://www.google.com/search?client=firefoxd\&q=Sudarsono $\% 2 \mathrm{C}+2021 .+$ Tanggap $+\mathrm{Co}$ vid-19+Provinsi+Jawa+Tengah+\%2816\%2F05\%2F2021\%29++Diakses, 19 Juli 2021, Jam 22.00

[9] KILPATRICK, WILLIAM HEARD. 1941. Selfhood and Civilization: A Study of the SelfOther Process. New York: Macmillan.

[10] Lickona, Thomas. 1991. Educating for Character How Our Scholls Can Teach. Respect and Responsibility. New York: Bantan Book. 